\title{
Shortening of Pseudomonas aeruginosa Pili after RNA-Phage Adsorption
}

\author{
By D. E. BRADLEY \\ Department of Zoology, University of Edinburgh, \\ West Mains Rd, Edinburgh, EH9 3 JT
}

(Accepted for publication 25 April 1972)

\begin{abstract}
SUMMARY
The F-pilus retraction theory suggests that F-pili retract on contact with a recipient bacterium or pilus-specific bacteriophage, but there has been no direct demonstration of any form of pilus retraction. Electron microscopy is used here to study average length changes in Pseudomonas aeruginosa RNA-phage pili after the adsorption of RNA-phage virions to the sides. The theory predicts that, if one phage per pilus is adsorbed, there should be a reduction of about $50 \%$ in the mean length due to the adsorption of virions at random points; retraction would be stopped at the point of adsorption when the virus reached the bacterial surface. A phage-resistant, pilus-bearing $P$. aeruginosa strain (PAO68), used as a control, showed no such change. The phage-sensitive strain PAOI showed an average reduction in pilus length of about $42.5 \%$ relative to its length before adsorption, or $50 \%$ relative to the PA068 average. This strongly suggests pilus retraction in PAOI but not in PA068. In electron micrographs, phage virions are seen almost always at the bases of PAOI pili, whereas virions adsorbed to PA068 are randomly distributed along the pili.
\end{abstract}

\section{INTRODUCTION}

Pseudomonas aeruginosa possesses numerous thin polar filaments or pili. They have been studied in some detail and are known to act as receptors for RNA bacteriophages (Bradley, I966; Fuerst \& Hayward, I969; Weppelman \& Brinton, I97I) and probably filamentous phages (Bradley, 1972). They are similar to Escherichia coli F-pili in this respect (Brinton, Gemski \& Carnahan, I964; Caro \& Schnös, I966), but differ in that they do not appear to be involved in conjugation and genetic transfer (Holloway, 1969). The exact function of both kinds of pili is uncertain, but a concept known as the 'F-pilus reaction model' has been suggested by Marvin \& Hohn (1969) and Curtiss (1969) for E. coli. It is of fundamental importance in understanding bacterial mating and the injection processes of RNA and filamentous bacteriophages. It suggests that the attachment of the pilus to a receptor on the wall of a recipient bacterium results in a signal passing down the filament to a mechanism at its base, causing it to retract, probably by a depolymerization process. Mating and the transfer of $\mathrm{F}$ is thus brought about by drawing the two bacteria into contact. The actual transfer of genetic material is believed to take place through a classical conjugation bridge (Anderson, Wollman \& Jacob, 1957). This idea is radically different from that of Brinton (1965) who suggested that F-pili act as tubes for nucleic acid conduction. The retraction theory was based largely on strong circumstantial evidence provided by observations on the adsorption and injection processes of RNA and filamentous coliphages. The model suggests that RNA phages, which adsorb to the sides of the pilus, trigger retraction and are pulled into contact with the bacterial wall where they inject their RNA (see Fig. Io). It was found 
that filamentous phages, which adsorb to the pilus tip (Caro \& Schnös, 1966) entered the bacterium in their entirety (Trenkner, Bonhoeffer \& Gierer, 1967). This suggested that the pili had pulled them inside, but more recent results (Henry \& Brinton, 197I) indicate a more complex process which could be equally compatible with the conduction theory.

The evidence, fully documented by Marvin \& Hohn (1969) and Bradley (1972), is at present indirect, there being no observations giving direct visual proof for either Escherichia coli F-pili or Pseudomonas aeruginosa pili. However, Bradley (1972) observed by electron microscopy and negative staining that the average number of pili per bacterium after RNAphage adsorption to $P$. aeruginosa strain PAOI (Holloway strain I) pili was up to 25 times greater than before adsorption. The implication was that the specimen preparation process caused most of the pili to disappear, probably by retraction into the bacterium. Adsorbed RNA-phage virions prevented this so that many more pili were visible. These results provided the basis for the experiments to be described here. They are designed to demonstrate pilus retraction by stopping it after it has proceeded for a measurable length. The adsorption of one phage per pilus should allow the average length of a number of pili to be reduced by about a half. This would be so if individual adsorption sites were randomly distributed along the lengths of the pili, permitting a random amount of retraction, which would average out at a half.

While studying piliation on some strains of Pseudomonas aeruginosa, Bradley (1972) found two having pili to which RNA phages adsorbed, but which were resistant to infection. Moreover, they showed no increase in the number of pili present after adsorption. It was suggested that these strains were phage-resistant because the pili could not retract and permit RNA penetration. One of these strains is included as a control in the experiment mentioned above, as there should be no difference in the average pilus length after phage adsorption. Some additional experiments are included to clarify the behaviour of $P$. aeruginosa pili under the influence of both phage adsorption and negative staining.

Two, possibly three, different kinds of pili are known for Pseudomonas aeruginosa (Bradley, 1972). The type studied here will be referred to as RNA-phage pili. They do not act as receptors for filamentous phages, which appear to infect via morphologically similar pili on a serologically different strain from that infected by the RNA phage.

\section{METHODS}

Bacteria and bacteriophage. The RNA phage used, ATCC 252478, was PP7 (Bradley, I966). Pseudomonas aeruginosa strain PAOI (Holloway, I955), the original strain I wild-type, was originally supplied by Dr T. Feary. It has been redeposited as the host for PP7 (ATCC 25247). The strain resistant to $\mathrm{PP}_{7}$, PA068, was kindly supplied by Professor B. W. Holloway. It originated from PAOI but has the genotype trp-54, str-r, chl-r.

Culture media. Oxoid nutrient broth was used for broth and agar plate cultures, the latter containing $2 \%(\mathrm{w} / \mathrm{v})$ agar. Bacteria were grown in about $25 \mathrm{ml}$ of broth in a $250 \mathrm{ml}$ conical flask shaken in a water bath at $37^{\circ} \mathrm{C}$ at about 2 oscillations/s. Phage $\mathrm{PP}_{7}$ stocks were grown by lysing confluent bacterial growth on $15 \mathrm{~cm}$ diameter plates by means of the doubleagar-layer method of Adams (I959) with $0.5 \%$ (w/v) agar in the top layer. Phages were extracted from each plate with $\mathrm{I} 0 \mathrm{ml}$ of broth, being oscillated at 2 oscillations/s for $2 \mathrm{~h}$ at room temperature. This gave a titre of about $\mathrm{I} \times \mathrm{ro}^{12}$ plaque-forming units (p.f.u.) $/ \mathrm{ml}$. Differential centrifugation was used for partial purification.

Preparation of antipilus serum. A specific rabbit antiserum to PAOI pili was prepared from a pilus suspension as follows. A I ml sample of an early log-phase culture of PAOI was 
spread evenly over each of six $15 \mathrm{~cm}$ diameter nutrient broth agar plates. After $24 \mathrm{~h}$ of incubation at $37^{\circ} \mathrm{C}$, the resulting lawns of bacteria were washed into $200 \mathrm{ml}$ of broth. The suspension was then blended in a Waring Blendor Model 2043 for six periods of $5 \mathrm{~s}$. Debris was centrifuged twice in a Spinco ' 30 ' rotor at $15000 \mathrm{rev} . / \mathrm{min}$ for $20 \mathrm{~min}$. The supernatant containing the pili was centrifuged in a ' 30 ' rotor at $30000 \mathrm{rev} . / \mathrm{min}$ for $26 \mathrm{~h}$. Each pellet was resuspended in about $\mathrm{I} \mathrm{ml}$ of broth and centrifuged at $7000 \mathrm{~g}$ for $\mathrm{I} 5 \mathrm{~min}$. The supernatant was checked for the presence of pili in the electron microscope with negative staining and the grid flotation method (see below). A $0.5 \mathrm{ml}$ sample was injected into rabbits subcutaneously with complete Freund's adjuvant. At 5 weeks, secondary antibody response was stimulated by a series of six intravenous injections of fresh pilus suspension of $0.75 \mathrm{ml}$ each at intervals of 2 to 3 days. One month after the last injection $\mathrm{I} \cdot 5 \mathrm{ml}$ of pilus suspension was given intravenously. The rabbits were bled 9 days later. The serum was heated at $56^{\circ} \mathrm{C}$ for $40 \mathrm{~min}$ to inactivate complement, and the $\mathrm{pH}$ corrected to $7 \cdot 2$. The serum was checked for specific antibody labelling of pili in the electron microscope by the grid-labelling method of Lawn (1967) described below. Antibodies adhered to the pili of PAOI, but not to those of Pseudomonas aeruginosa ATCC 25102 (see Bradley, 1972), host for a filamentous phage.

Electron microscopy. Negative staining was found more efficient than shadowcasting for the experiments described below and was carried out as follows. Carbon-coated support grids, made with a collodion substrate, were freshly washed in amyl acetate. They were then floated film downwards on water and transferred with a loop to the surface of a culture sample. The time of flotation varied from $30 \mathrm{~s}$ for a dense late log-phase culture to $5 \mathrm{~min}$ for a diluted mixture of phage and bacteria. The grids were transferred to two water baths for a total of about I min with slight agitation. Finally they were touched on to the surface of a solution of sodium phosphotungstate (NaPT) at $\mathrm{pH} 7.4$ and concentration 0.5 to $0.75 \%$ $(\mathrm{w} / \mathrm{v})$ depending on the structure being examined, and dried after the removal of excess solution with a filter paper.

Antibody-labelling of pili. The grid-labelling method of Lawn (1967) was carried out as follows. Bacteria were mounted on grids as above. After the first wash, before negative staining, they were transferred to the surface of suitably diluted antipilus serum and allowed to float with light agitation for I min. They were then washed twice and negatively stained. Heavy labelling was obtained with a $\mathrm{I}: 50$ antiserum dilution. Pili were also labelled in suspension. A quantity of bacterial culture was placed in a dish and diluted antiserum added to a final concentration of $\mathrm{I}: 50$ or $\mathrm{I}: \mathrm{I00}$. After gentle agitation for $30 \mathrm{~s}$ a grid was totally immersed in the mixture and continuously moved back and forth for a further $1 \cdot 5$ to 2 min. By this time the bacteria had agglutinated, and the grid was removed, washed twice, and negatively stained in $0.75 \%(\mathrm{w} / \mathrm{v}) \mathrm{NaPT}$.

Adsorption of phage $P_{7}$. In preliminary tests it was found that, regardless of the multiplicity of infection (m.o.i.), only I or 2 virions adsorbed to each pilus. To ensure rapid adsorption, a high m.o.i. was always used as follows. A sample of the culture was diluted with broth to $2 \times 10^{8}$ organisms $/ \mathrm{ml}$, measured by precalibrated optical absorption. A I ml sample was mixed with $\mathrm{I} \mathrm{ml}$ of $\mathrm{PP}_{7}$ suspension at $\mathrm{I} \times \mathrm{I}^{12}$ p.f.u. $/ \mathrm{ml}$ giving an m.o.i. of 5000 . The mixture, in a $250 \mathrm{ml}$ conical flask, was shaken gently at $37^{\circ} \mathrm{C}$ for 8 to $10 \mathrm{~min}$ and grids were then floated on it as described above for a further $5 \mathrm{~min}$ at room temperature. The total time was within the latent period of the phage (about $40 \mathrm{~min}$ ) so that no bacterial lysis occurred. The reasons for the adsorption behaviour were investigated, the results of qualitative observations in the electron microscope on the efficiency of adsorption at different $\mathrm{pH}$ values are given below. Pili or strains with adsorbed $\mathrm{PP}_{7}$ virions will henceforth be referred to as ' $\mathrm{PP}_{7}$-labelled'. 
Determination of the average number of pili per bacterium. Previous experiments (Bradley, 1972) indicated that a reasonably reproducible result could be obtained quickly by counting pili per bacterium in the electron microscope. The number of pili was therefore noted on each of at least 50 bacteria counted at random on a number of different grid squares, and the average pili per bacterium calculated.

Determination of the average pilus length in a culture. Electron micrographs were taken of single poles, not whole bacteria including both poles, of Pseudomonas aeruginosa organisms. Every effort was made to ensure a random sample. Usually, the first organism encountered on each grid square was photographed, followed by a limit of two more, taken at random. As many poles as practicable were recorded. The exception to this was unlabelled PAOr (without adsorbed phages). Here the pili were so few that all that could be found were photographed. Plates were taken at about I $8000 \times$ with a Siemens Elmiskop I and enlarged to about $50000 \times$. The microscope was calibrated by means of micrographs of $264 \mathrm{~nm}$ polystyrene latex spheres taken during the same session. Pili were always measured to the edge of the bacterium since many filaments originated from points 200 to $300 \mathrm{~nm}$ from the pole but were not clearly visible when covered by the body of the bacterium. The consequent error was the same for all samples so did not affect the comparative treatment given to the results. The lengths given are thus the average visible lengths. Actual measurement, accurate to within about $50 \mathrm{~nm}$, was carried out with a rule when pili were straight enough, and otherwise with a map measurer.

\section{RESULTS}

\section{Effect of $\mathrm{pH}$ on the adsorption of phage $\mathrm{PP}_{7}$}

Since the success of the experiments to be described depended upon the adsorption of correct numbers of $\mathrm{PP}_{7}$ virions, qualitative tests were carried out to ensure that the procedure used gave a reproducible result. The $\mathrm{pH}$ of a $5 \mathrm{~h}$ shake culture of PAOI was found to be $8 \cdot 2$. That of the phage suspension prepared by the methods described was $8 \cdot 4$. At a m.o.i. of 5000 , I or 2 virions/pilus were found in the electron microscope. However, when both phage suspension and bacterial suspension were made slightly acid to $\mathrm{pH} 6.8$ with $\mathrm{O} \cdot \mathrm{I} \mathrm{N}-\mathrm{HCl}$, many more virions were adsorbed. It was decided to maintain the natural alkalinity of a log-phase culture ( $\mathrm{pH} \mathrm{8.2)} \mathrm{throughout} \mathrm{the} \mathrm{experiments.} \mathrm{In} \mathrm{addition,} \mathrm{the} \mathrm{pH}$ of the negative stain used changed from an initial $7 \cdot 4$ to $7 \cdot 9$ just before drying as measured by the method of Bradley (1962). This ensured that neutral to alkaline conditions were maintained. A possible explanation for this difference in adsorption with $\mathrm{pH}$ is that many virions were reversibly adsorbed to the pili at the higher $\mathrm{pH}$ and were washed off in a manner similar to that found by Paranchych (I966) for RNA coliphages, but this is unlikely.

\section{Measurements of average visible length of pili}

Four experiments were carried out on log-phase cultures at $2.5,3.5$ and $4.5 \mathrm{~h}$, and on a resuspended $7 \mathrm{~h}$ plate culture. Samples measured in each case included PP7-labelled and unlabelled pili for strains PAOI and PA068. The average number of pili per bacterium and the average length measurements are given in Table I. The lengths for PP7-labelled PAOI pili are much less than those for the others. The distribution of lengths in each case is shown in the form of a histogram (Fig. I). Those from all four experiments are included to show the degree of reproducibility obtained. It can be seen that the pilus lengths for unlabelled PAOI and both PA068 samples are widely distributed in all experiments. For PP7-labelled PAOI, 
Table I. Average number of pili per bacterium and average pilus lengths for labelled and unlabelled Pseudomonas aeruginosa strains

\begin{tabular}{|c|c|c|c|c|c|c|}
\hline Culture & Strain & Treatment & $\begin{array}{c}\text { Average } \\
\text { pili/bacterium }\end{array}$ & $\begin{array}{l}\text { Average pilus } \\
\text { length }(\mathrm{nm})\end{array}$ & $\begin{array}{l}\text { No. of } \\
\text { pili }\end{array}$ & $\begin{array}{l}\text { No. of } \\
\text { poles }\end{array}$ \\
\hline \multirow[t]{6}{*}{$2.5 \mathrm{~h}$} & \multirow[t]{3}{*}{ PAOI } & Unlabelled & 0.37 & I 353 & 100 & $7 \mathrm{I}$ \\
\hline & & PP7-labelled & $8 \cdot 4$ & 664 & 223 & 39 \\
\hline & & $\begin{array}{l}\text { Antibody } \\
\text { labelled }\end{array}$ & $4 \cdot 0$ & 1209 & 79 & 25 \\
\hline & \multirow[t]{3}{*}{ PAO68 } & Unlabelled & $3 \cdot 8$ & 1407 & 102 & 38 \\
\hline & & PP7-labelled & $5 \cdot 5$ & 1280 & 173 & 34 \\
\hline & & $\begin{array}{l}\text { Antibody- } \\
\text { labelled }\end{array}$ & $5 \cdot 4$ & I 350 & 108 & 20 \\
\hline \multirow[t]{4}{*}{$3.5 \mathrm{~h}$} & \multirow[t]{2}{*}{ PAOI } & Unlabelled & 0.2 & I 206 & I 13 & 87 \\
\hline & & PP7-labelled & $10 \cdot 6$ & 738 & 229 & 40 \\
\hline & \multirow[t]{2}{*}{ PAO68 } & Unlabelled & $6 \cdot 2$ & I 26 I & 194 & 42 \\
\hline & & PP7-labelled & $6 \cdot 9$ & I 230 & 239 & 42 \\
\hline \multirow[t]{6}{*}{$4.5 \mathrm{~h}$} & \multirow[t]{3}{*}{ PAOI } & Unlabelled & 0.83 & 859 & 125 & $7 \mathrm{I}$ \\
\hline & & PP7-labelled & $7 \cdot 6$ & 490 & 177 & 36 \\
\hline & & $\begin{array}{l}\text { Antbody- } \\
\text { labelled }\end{array}$ & 3.4 & 597 & I 3 I & 53 \\
\hline & \multirow[t]{3}{*}{ PAO68 } & Unlabelled & $6 \cdot 8$ & I I 58 & 220 & 46 \\
\hline & & PP7-labelled & 10.4 & I 303 & 331 & 44 \\
\hline & & $\begin{array}{l}\text { Antibody- } \\
\text { labelled }\end{array}$ & $7 \cdot 5$ & I I 21 & I 73 & 42 \\
\hline \multirow{4}{*}{$\begin{array}{l}7 \mathrm{~h} \\
\text { plate }\end{array}$} & \multirow[t]{2}{*}{ PAOI } & Unlabelled & $1 \cdot 7$ & I 304 & 132 & 53 \\
\hline & & PP7-labelled & I 4.4 & 819 & 362 & 39 \\
\hline & \multirow[t]{2}{*}{ PAO68 } & Unlabelled & $1 \mathrm{I} \cdot 5$ & I 668 & 256 & 44 \\
\hline & & PP7-labelled & $9 \cdot 9$ & I 486 & 307 & 39 \\
\hline
\end{tabular}

however, there is a marked shift towards the shorter lengths particularly in Fig. I (a) and (c) bottom histograms.

In addition, lengths of antibody-labelled pili in the $2.5 \mathrm{~h}$ and $4.5 \mathrm{~h}$ cultures were measured. Some difficulty was experienced in counting and measuring these pili due to tangling, but the reason for their inclusion will be given below. The results are included in Table $\mathrm{I}$. The appearance of PAO68 pili labelled with antipilus antibodies for PAOI is illustrated in Fig. 2, which also confirms that PAO68 and PAOI pili share a common antigen.

\section{Positions of the adsorbed virions}

With PAOI, almost all the phages were attached to the bases of the pili as shown in Fig. 3. On the right, two pili have broken off, probably at the bases; one pilus has two virions attached to its base (arrowed). With PA068, the virions were randomly distributed well away from the bases, and it was difficult to find one in contact with the cell (Fig. 4). Also noted, on unlabelled PAOI bacteria only, were a number of what appeared to be small black dots on the bacterial surface in the region of the poles (Fig. 5 to 8 , arrowed).

\section{Determination of the cause of pilus loss in unlabelled PAOI bacteria}

The difference in the number of pili per bacterium between unlabelled and labelled PAOI bacteria shown in Table I was believed to be caused by the specimen preparation process. The following tests were therefore carried out to determine at which stage the pili disappeared in the unlabelled samples. It is clear from Table $I$ that the loss of pili is reduced by labelling 

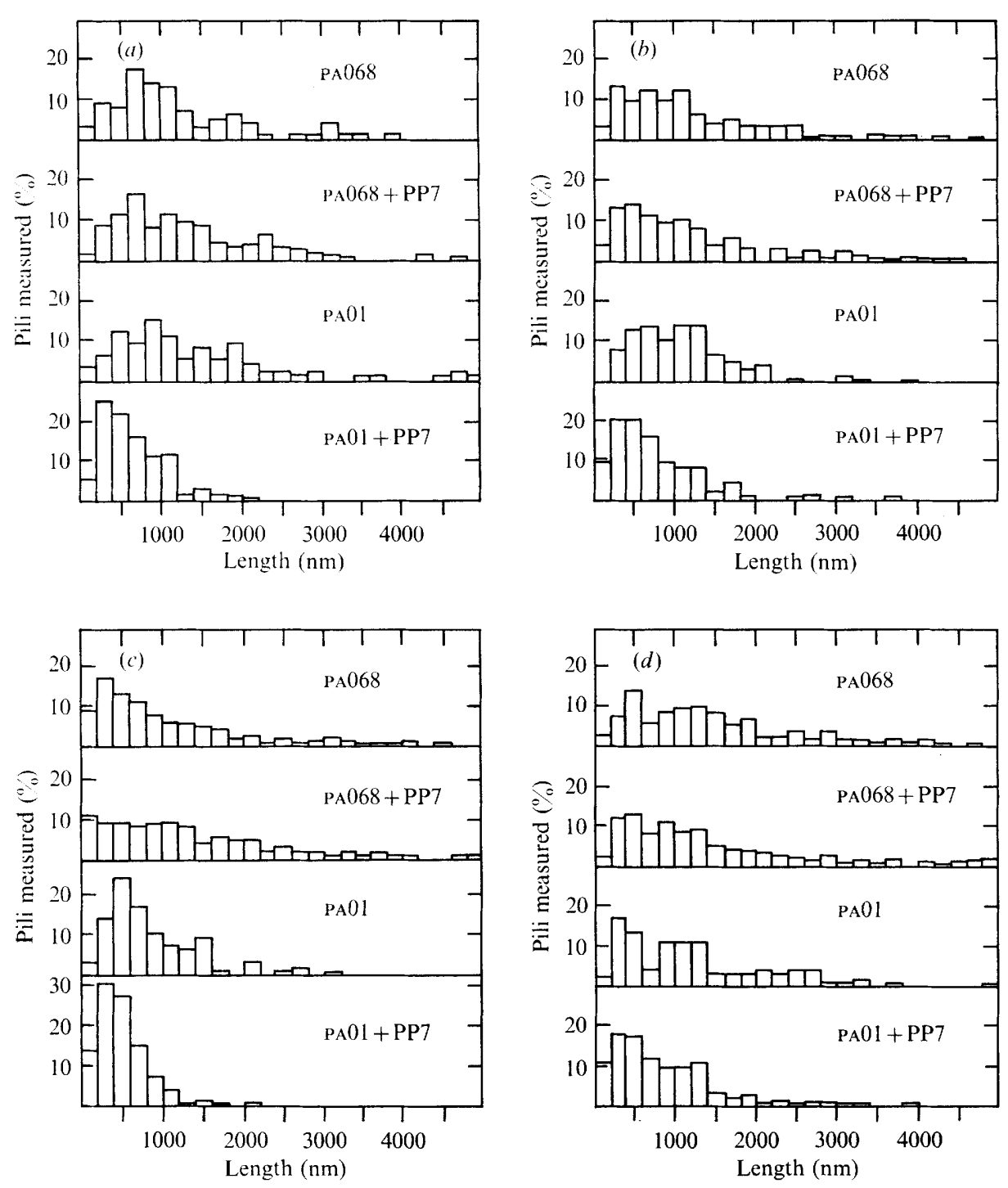

Fig. I. Average visible length distribution of pili in samples of Pseudomonas aeruginosa strains PAOI and PA068 before and after labelling with phage PP7. (a) $2.5 \mathrm{~h}$ broth culture; (b) $3.5 \mathrm{~h}$ broth culture; (c) $4.5 \mathrm{~h}$ broth culture; $(d) 7 \mathrm{~h}$ plate culture. Samples labelled with phage $\mathrm{PP} 7$ are marked '+ PP7'.

in suspension with antibodies or phage, the latter being more efficient. A similar preservation was attained by labelling with antibodies after the bacteria had been mounted on the grid (Lawn, 1967). The next test was to omit the use of NaPT and to substitute platinum shadowcasting on unlabelled PAOr bacteria. Control pilus counts on negative stained unlabelled and PP7-labelled bacteria were included, and the results are shown in Table 2 . The percentage of piliated bacteria in each sample is included. It can be seen that rather less than half the pili are present in the shadowed sample compared to the PP7-labelled negative-stained sample. 


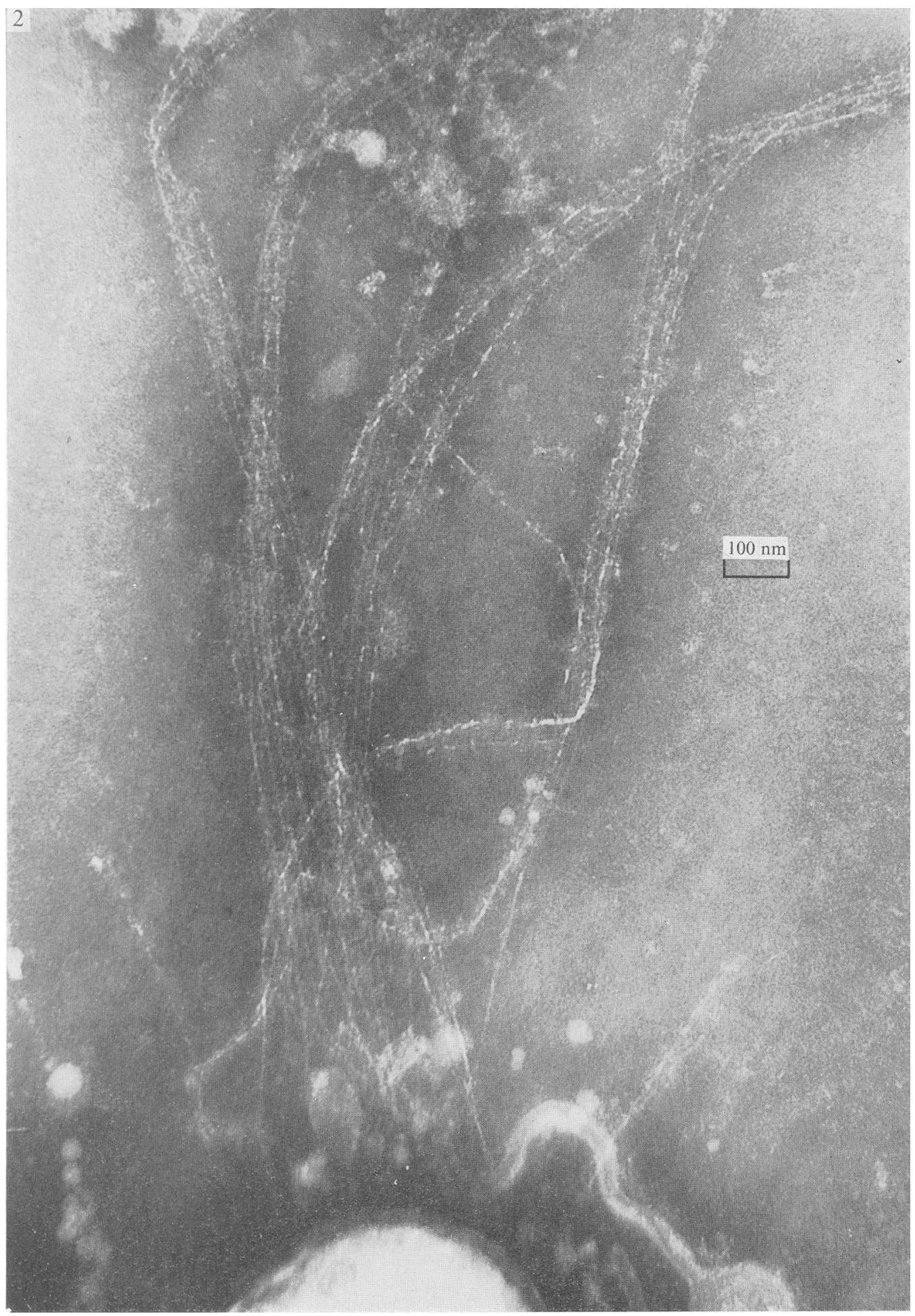

Fig. 2. Pseudomonas aeruginosa strain PA068 showing pili labelled with antibodies to strain PAOI pili. 


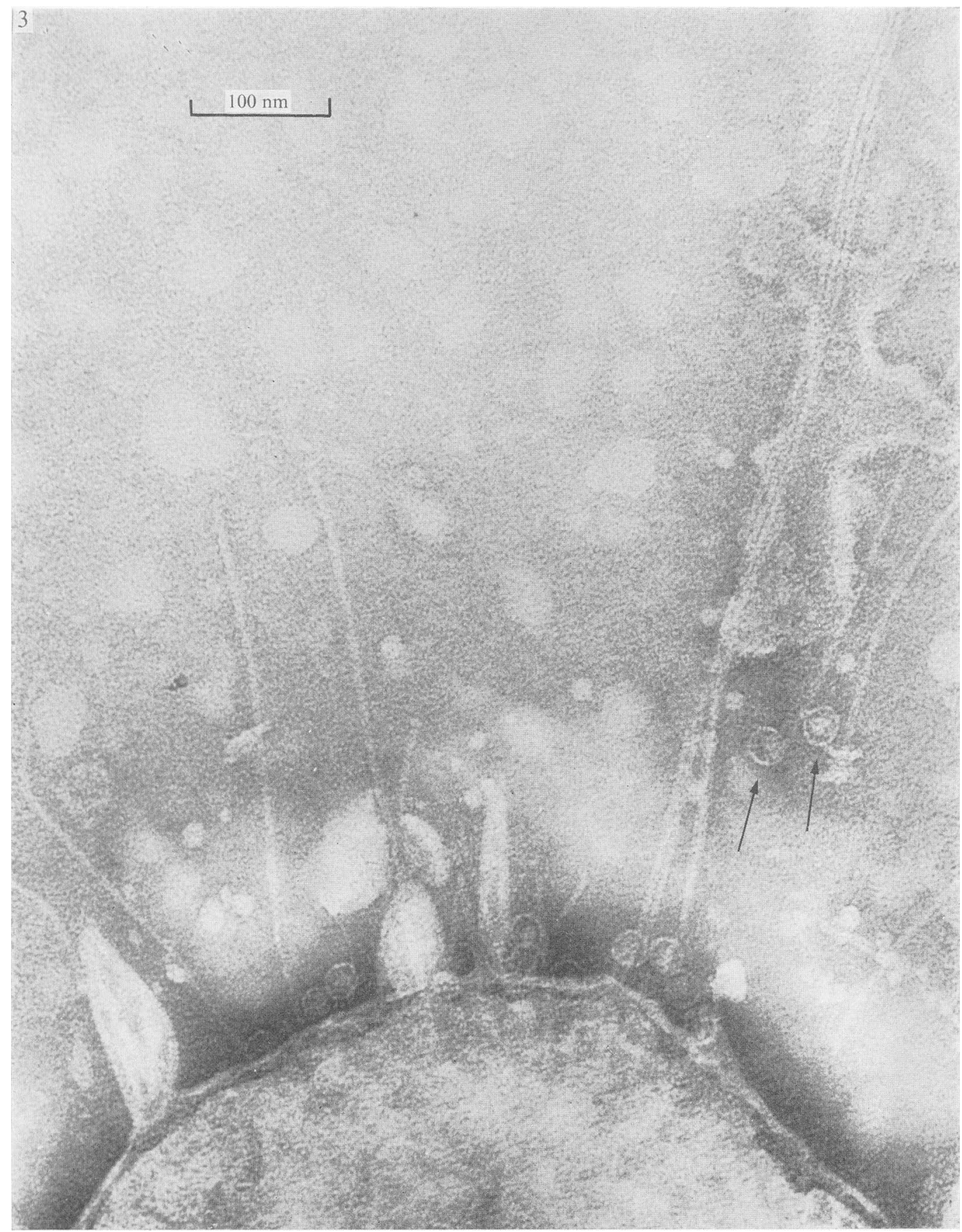

Fig. 3. Pseudomonas aeruginosa strain PAOI with adsorbed phage $\mathrm{PP}_{7}$ virions at the bases of the pili. Arrows mark two virions at the base of a pilus which has broken off. 


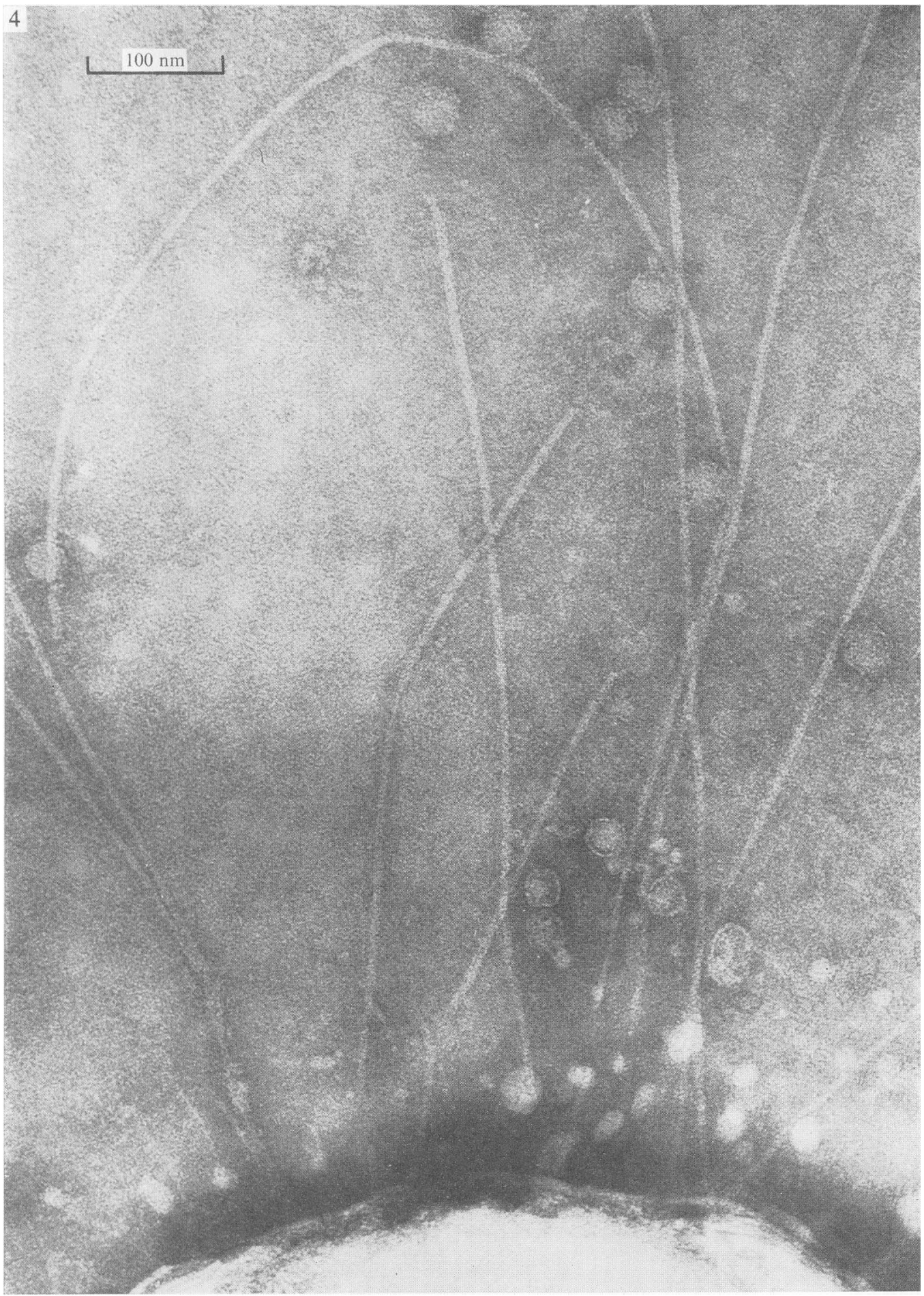

Fig. 4. Pseudomonas aeruginosa strain PA068 with adsorbed phage PP7 virions randomly distributed along the pili with none at the bacterial surface. 
The effect of NaPT was determined next. The bacteria were mounted on a grid, floated on $\mathrm{I} \%(\mathrm{w} / \mathrm{v}) \mathrm{NaPT}$ solution for I min, treated with antiserum to prevent the loss of pili, then negatively stained as usual. The control was a similar grid omitting the NaPT wash. The results, together with negative-stained unlabelled and $\mathrm{PP} 7$-labelled samples for comparison, are shown in Table 3. It can be seen that the NaPT was responsible for a very considerable loss of pili, only about $12 \%$ remaining after treatment.

\section{Antibody-labelling of $\mathrm{PAOI}$ pili after PP7-labelling}

The previous observation of PP7-labelled, NaPT-stained preparations suggested that the pili had shortened in some way because the phage virions were all at the bases of the filaments in the case of PAOI only. However, it was not indicated whether the phage or the negative stain was responsible. This test was designed to settle the point by labelling with $\mathrm{PP}_{7}$ in the normal way, adding antiserum to a final concentration of $\mathrm{I}: \mathrm{I}$ oo, then negatively staining. The antibodies would thus stop any shortening of pili caused by NaPT, but not by adsorbed virions. As has been mentioned, tangling of the pili caused some confusion, but with few exceptions, the virions were still at the bases of the pili (Fig. 9).

\section{DISCUSSION}

The retraction model applied to RNA-phage infection. Before discussing the results, it is necessary to clarify the application of the retraction theory to RNA-phage adsorption and injection. Fig. Io illustrates the four stages involved: $(a)$ adsorption to the pilus; $(b)$ ejection of a short length of RNA on to the pilus surface; $(c)$ retraction of the pilus until the exposed RNA enters the cell; $(d)$ final penetration of the viral RNA. The only evidence available supports the second step: the presence of RNase in the growth medium of an infected culture prevents the formation of plaques on a double agar layer plate (Loeb \& Zinder, I96I ; Bradley, 1966; Paranchych, 1966). The RNA would hardly be accessible to RNase if it was injected into the pilus lumen as suggested by Valentine \& Wedel (1965) and by Silverman \& Valentine (1969), who also suggested that the empty capsid of coliphage f 2 became detached after penetration had been completed. However, $\mathrm{PP}_{7}$ phage virions remain at the pilus base as predicted (Fig. 3, Iod). This could be interpreted as a visual manifestation of retraction. The control strain PA068 shows virions randomly distributed along the pili (Fig. 4), strongly favouring the suggestion (Bradley, 1972) that resistance to $\mathrm{PP}_{7}$ is associated with the inability of the pili to retract. Presumably the ability of pili to retract could have been lost by strain PA068 in the course of its evolution from strain PAOI.

The shortening of $\mathrm{PAOI}$ pili after $\mathrm{PP}_{7}$ adsorption. The results of the measurements described here depend to some extent on the examination of a random sample from the bacterial population. It may be argued that adsorption to grids could produce some form of selection. To affect the results, this would have to favour bacteria having pili (with phage or antibodies attached) which were shorter than normal, a situation difficult to conceive. Also the more or less similar average pilus lengths obtained for the PP7-labelled control strain (PA068) compared to unlabelled PAOI would seem to preclude any selection of this nature. I am of the opinion that there is no significant selection in the method used for mounting motile bacteria.

The question of breakage must also be considered. The measurement of pilus lengths in the control strain was carried out partly to eliminate this possibility. It must be remembered that PAO68 originated from PAOI, that its pili adsorb phage $\mathrm{PP}_{7}$ and that they are serologically related and morphologically similar to PAOI pili. It is thus very unlikely indeed that they 

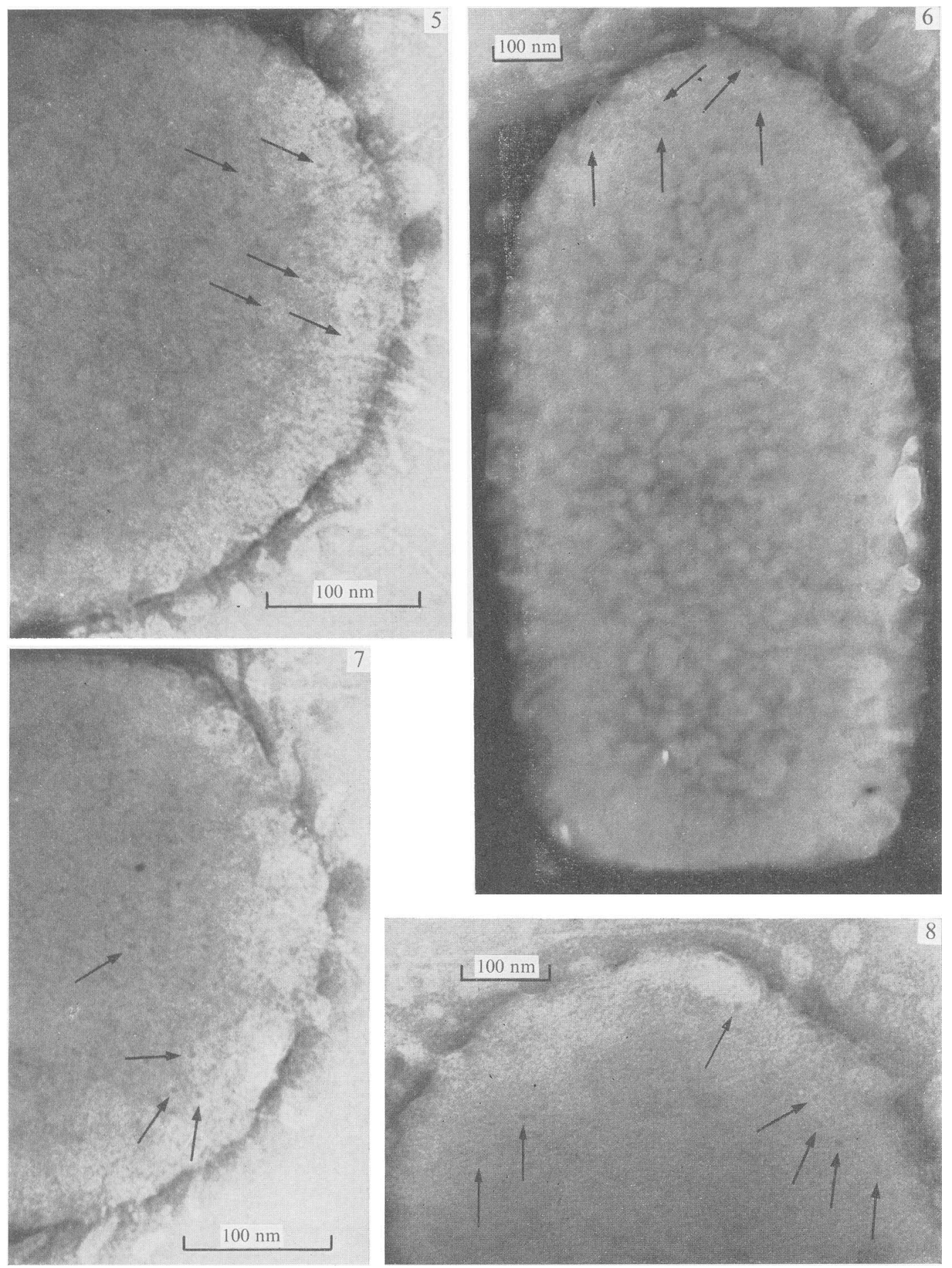

Fig. 5 8. Unlabelled Pseudomonas aeruginosa strain PAOI bacterium from a plate culture showing very small dark spots (arrows) at the pole, thought to represent holes through which pili protruded before retraction. 
Table 2. Extent of piliation of PAOI from a 5 culture, determined by means of shadowcasting

$\begin{array}{lcc} & \begin{array}{c}\text { Bacteria } \\ \text { piliated } \\ (\%)\end{array} & \begin{array}{c}\text { Average } \\ \text { pili/bacterium }\end{array} \\ \text { Treatment } & 35.5 & 0 \cdot 5 \\ \text { Unlabelled, NaPT } & 84 & 2 \cdot \mathrm{I} \\ \text { Unlabelled, shadowed } & 92 \cdot 5 & 5.8 \\ \text { PP7-labelled, NaPT } & 9.5\end{array}$

Table 3. The effect of NaPT treatment on PAOI piliation in a $3.5 \mathrm{~h}$ culture

$\begin{array}{lcc} & \begin{array}{c}\text { Bacteria } \\ \text { piliated } \\ (\%)\end{array} & \begin{array}{c}\text { Average } \\ \text { pili/bacterium }\end{array} \\ \text { Treatment } & 100 & 10 \cdot 6 \\ \text { PP7-labelled, NaPT } & 14 \cdot 5 & 0 \cdot 2 \\ \text { Unlabelled, NaPT } & 84 & 4 \cdot 3 \\ \begin{array}{c}\text { Antibody-labelled } \\ \text { on grid, NaPT }\end{array} & & 0.5 \\ \begin{array}{l}\text { Wash NaPT, antibody- } \\ \text { labelled on grid, NaPT }\end{array} & 27 & \end{array}$

differ in their mechanical properties so that those of PA068 are significantly stronger. Furthermore, it is hardly conceivable that phage adsorption could have caused breakage and at the same time induced a very large increase in the numbers of pili per bacterium (Bradley, 1972).

It is clear from the sample sizes, etc., that one cannot justifiably treat the numerical results given here statistically. However, it can be said that $\mathrm{PP}_{7}$ adsorption produced a substantial shortening relative to unlabelled PAOr and all PA068 pili. The histograms in Fig. I indicate the manner in which this occurred. For PAOI, the percentages of shorter pili were much greater after labelling than beforehand. For PAO68 there was virtually no difference. This was consistent with the retraction of pili in the case of PAOI, but not with PA068. The amount of shortening for each culture is shown in Table 4. What represents the true length (not shortened) for PAOI pili? There are two possibilities. Since PA068 has pili which are serologically related to those of PAOr, and was derived from it, it is reasonable to assume that the average length of its pili is close to that of unshortened PAOr pili. The second possibility is that the residual pili in unlabelled PAor cells did not shorten because they were defective in some way, perhaps in the hypothetical depolymerization mechanism. In both cases they will represent the true average unshortened length. Both possibilities are included in Table 4 and it can be seen that the difference is comparatively small, though in two instances ( $4.5 \mathrm{~h}$ broth and $7 \mathrm{~h}$ plate cultures) the unlabelled PAor length is somewhat shorter than the two PA068 lengths. Since the retraction theory predicts that the initial length of the pili before adsorption will not affect the percentage of retraction, an average for this over the four experiments is a useful figure. The prediction of the retraction model appears to have been fulfilled.

The reason for including the average lengths for antibody-labelled pili is to show that an agent other than RNA phages can prevent shortening. While the figures are generally rather less than those obtained for the unshortened pili (as defined above), it is presumed that this is mainly because of the difficulty of measurement, the longer filaments becoming too 


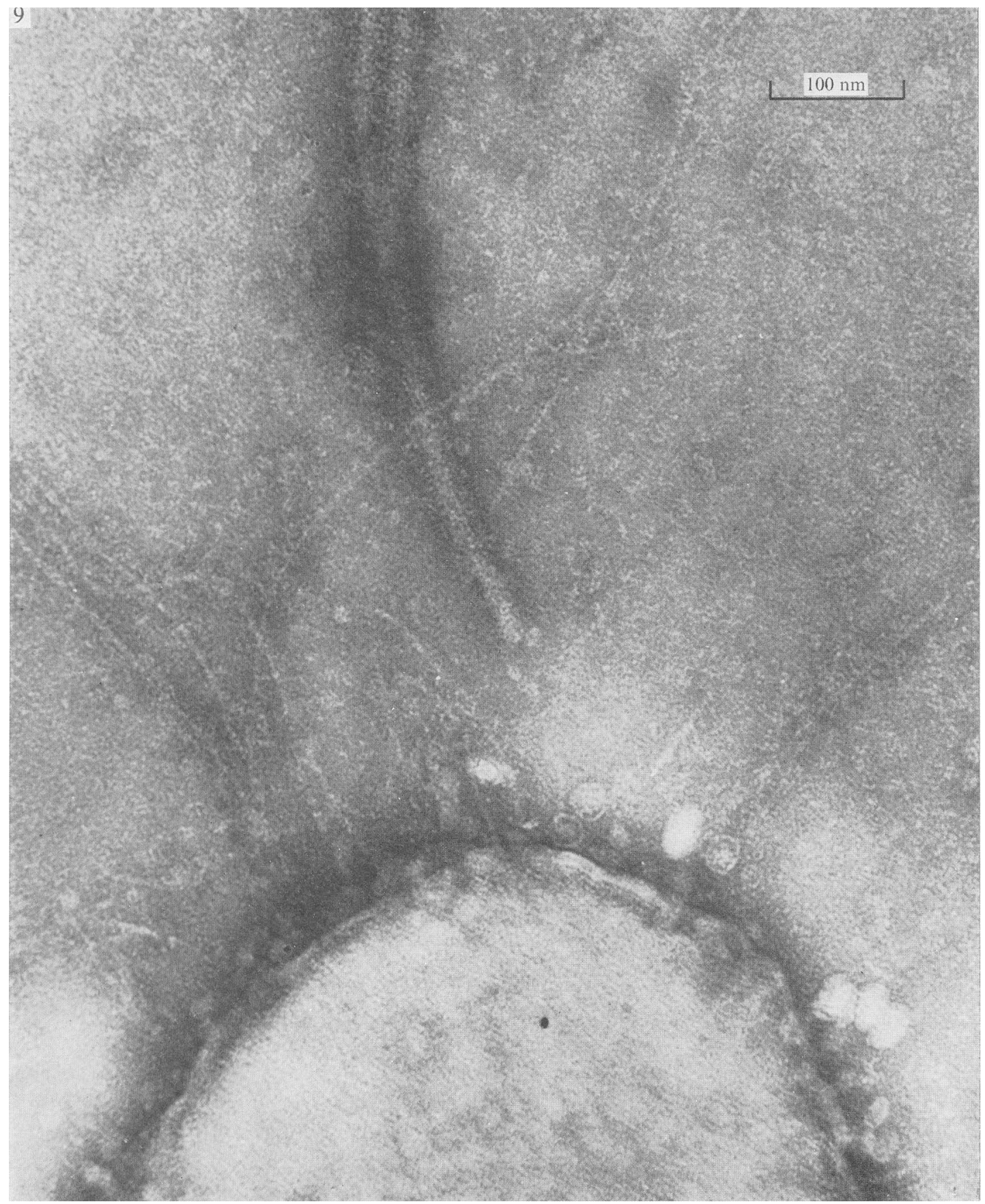

Fig. 9. A Pseudomonas aeruginosa strain PAOI bacterium which has been labelled with phage $\mathrm{PP}_{7}$, then with antipilus antibodies to stop possible retraction during subsequent negative staining. The virions are at the pilus bases showing that they caused shortening before NaPT treatment. The flagellum is also coated with antibodies because the antigen (pilus suspension) also contained fiagella. 


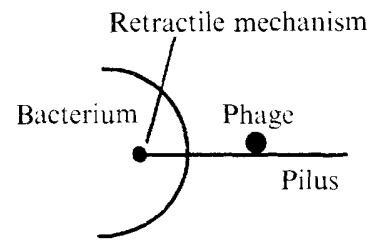

(a)

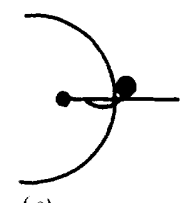

(c)

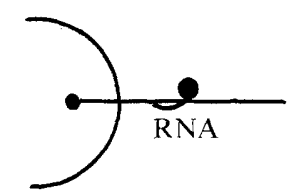

(b)

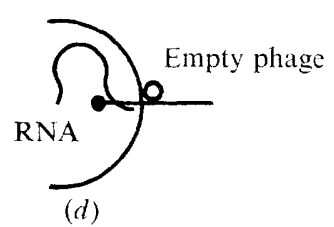

Fig. 10. Diagram of the adsorption and penetration steps of RNA-phage infection as suggested by the pilus-retraction model. (a) Adsorption to the pilus; (b) ejection of a short length of RNA on to the pilus surface; (c) retraction of the pilus and penetration of the surface RNA; $(d)$ penetration of the rest of the viral RNA.

Table 4. Average percentage shortening of $\mathrm{PP} 7$-labelled $\mathrm{PAOI}$ pili

\begin{tabular}{|c|c|c|c|c|c|}
\hline Culture & Strain & Treatment & $\begin{array}{l}\text { Average } \\
\text { pilus length } \\
\text { trom } \\
\text { Table I } \\
\text { (nm) }\end{array}$ & $\begin{array}{c}\text { Percentage } \\
\text { shortening } \\
\text { reference } \\
\text { unlabelled } \\
\text { PAOI pili }\end{array}$ & $\begin{array}{c}\text { Percentage } \\
\text { shortening } \\
\text { reference } \\
\text { PAO68 } \\
\text { pili* }\end{array}$ \\
\hline \multirow[t]{2}{*}{$2 \cdot 5 \mathrm{~h}$} & PAOI & $\begin{array}{l}\text { Unlabelled } \\
\text { PP7-labelled }\end{array}$ & $\begin{array}{r}1.353 \\
664\end{array}$ & $\overline{5 I}$ & $\overline{50}$ \\
\hline & PA068 & $\left.\begin{array}{l}\text { Unlabelled } \\
\text { PP7-labelled }\end{array}\right\}$ & $1327^{*}$ & - & - \\
\hline \multirow[t]{2}{*}{$3.5 \mathrm{~h}$} & PAOI & $\begin{array}{l}\text { Unlabelled } \\
\text { PP7-labelled }\end{array}$ & $\begin{array}{r}1206 \\
7: 8\end{array}$ & - & $\overline{4 I}$ \\
\hline & PAO68 & $\left.\begin{array}{l}\text { Unlabelled } \\
\text { PP7-labelled }\end{array}\right\}$ & $12-4^{*}$ & - & - \\
\hline \multirow[t]{2}{*}{$4.5 \mathrm{~h}$} & PAOI & $\begin{array}{l}\text { Unlabelled } \\
\text { PP7-labelled }\end{array}$ & $\begin{array}{l}8 \leq 9 \\
490\end{array}$ & $\overline{43}$ & $\overline{6 I}$ \\
\hline & PAO68 & $\left.\begin{array}{l}\text { Unlabelled } \\
\text { PP7-labelled }\end{array}\right\}$ & $12+5^{*}$ & - & 一 \\
\hline \multirow[t]{2}{*}{$\begin{array}{l}7 \mathrm{~h} \\
\text { plate }\end{array}$} & PAOI & $\begin{array}{l}\text { Unlabelled } \\
\text { PP7-labelled }\end{array}$ & $\begin{array}{r}1304 \\
81.5\end{array}$ & $\overline{37}$ & $\overline{48}$ \\
\hline & PAO 68 & $\left.\begin{array}{l}\text { Unlabelled } \\
\text { PP7-labelled }\end{array}\right\}$ & $156 x_{2} *$ & - & - \\
\hline
\end{tabular}

Average $42 \cdot 5$ Average 50

* Since there is little change in the average length of PA068 pili before and after $\mathrm{PP}_{7}$-labelling there is no shortening Consequem.y a combined average figure can be used for the unretracted length. 
tangled. However, it is important to establish the effect of antibodies on the average pilus length, because their stabilizing ability is used in the tests which indicate the probable causes of what is thought to be retraction.

The causes of pilus shortening. It has been shown that the NaPT used in negative staining causes loss of pili, and by inference, their shortening Bradley (1972) found that even fixatives, including $\mathrm{I} \%(\mathrm{w} / \mathrm{v}) \mathrm{OsO}_{4}$, caused their disappearance. Since NaPT is applied after $\mathrm{PP}_{7}$ in the normal preparation process, it might be argued that the NaPT, not the adsorbed virions, cause the pili to shorten. The test in which pili were labelled with antibodies after PP7 adsorption was designed to clear up this point. It has been shown in Tables $I$ and 3 that antibody-labelling maintains the pilus lengths. It is obvious that if no shortening had taken place on adsorption, the virions would not be at the bases of the pili at the time when the antibodies were attached. They would be randomly distributed. Since this was not the case, the virions must have been at the bases of the pili before antibody-labelling and hence induced pilus shortening as indicated in Fig. IO $(c)$. This is supported by the behaviour of strain PA068, whose pili do not shorten and which is PP7-resistant, inferring that shortening (probably retraction) is required for infection. The results of this experiment are consistent with the proposition that RNA-phage adsorption causes pilus retraction in Pseudomonas aeruginosa.

Very recently, Lawn \& Meynell (1972) have demonstrated an increase in the number of R-pili on Escherichia coli after labelling with specific antibodies. The order of magnitude was similar to that given here (Table I) and by Bradley (1972) for antibody- and phagelabelled bacteria. Lawn \& Meynell (1972) and Bradley (1972) explain the phenomenon by pilus retraction or the stimulation of additional pilus synthesis by antibody or phage adsorption. Some experimental data is at variance with the latter possibility. After treating PAOI cells with $0.1 \%(\mathrm{w} / \mathrm{v}) \mathrm{OsO}_{4}$, Bradley (1972) observed a sevenfold increase in the number of pili per bacterium compared to untreated bacteria. This suggests a significant preservation of pili already extended before treatment but which disappear if the $\mathrm{OsO}_{4}$ is omitted. As has been mentioned, a higher concentration $(\mathrm{I} \cdot 0 \%, \mathrm{w} / \mathrm{V})$ of the fixative caused disappearance, perhaps by setting up rapid retraction before it penetrated the bacterium. If this were so, the lower concentration of fixative would be insufficient to cause retraction but sufficient to fix the pilus-dissociating system. Since a fixative couli hardly stimulate pilus synthesis, prevention of retraction is considered the most likely explanation for the effect of the $0.1 \%$ (w/v) $\mathrm{OsO}_{4}$.

Shadowcasting, which omits chemical treatments from the specimen-preparation process, also produced a similar increase in piliation (Table 2 ) in unlabelled PAOI bacteria compared to negatively stained bacteria. It seems almost certain that the additional shadowed pili were present before the bacteria were mounted because there was nothing in the preparation process to induce their synthesis. The process of mounting and drying did, however, cause some loss in pili compared to PP7-labelled, negatively stained bacteria (Table 2). The inference is that contact with a solid surface (the carbon film) or the physical process of drying could cause some pili to disappear, presumably by retraction.

Table 3 shows that antibody-labelling of PAOI bacteria on the grid gave a large increase in pili per bacteria compared to unlabelled bacteria. This does not fit the concept of antibodies stimulating pilus production (Lawn \& Meynell, 1972) for the following reason. The labelling of the bacteria only involved $\mathrm{I}$ min contact with the antiserum in water at $20^{\circ} \mathrm{C}$, and it is unlikely that this could have stimulated and completed pilus production. While the results (particularly the shortening of the pili and the position of the virions at the bases of the pili) strongly favour retraction, it may be that there is a complex situation involving 
both retraction and stimulation of pilus synthesis. However, Pseudomonas aeruginosa RNAphage pili may not necessarily behave in the same way as R- and F-pili.

The appearance of negatively stained bacteria. In Fig. 5 to 8, a number of small dark dots can just be distinguished on the surface of bacteria lightly negatively stained with NaPT. Since a dark region represents a thick area of stain, a hole filled with NaPT will appear as a dark spot. Because these spots were confined to the poles of the bacteria (Fig. 6) and were only found on unlabelled PAOI, which had very few pili, I believe that they represent the holes in the bacterial envelope through which the pili had protruded before retraction. A possible interpretation is that the hypothetical depolymerization mechanism pulled the filaments right through the bacterial envelope.

Conclusion. By far the most likely explanation for the phenomena observed here is that the pili retract, and the experimental evidence is in agreement with the model shown in Fig. Io. It has also been shown that certain chemicals and contact with a solid or perhaps liquid surface can cause the pilus shortening believed to be brought about by retraction. If there are no adsorbed virions or antibodies on the pili, and shortening is initiated chemically, the filaments are apparently pulled right into the bacterium. A pilus assembly would thus seem to be very sensitive, the mechanism at its base being primed to pull it inwards (assuming retraction) as soon as any stimulus is applied. The process is also very rapid. A rough estimate for the rate of shortening based on the time taken for negative staining during which the shortening (disappearance of unlabelled pili) took place, and the lengths of the longer pili, is of the order of $100 \mathrm{~nm} / \mathrm{s}$.

There seems to be no single way of demonstrating pilus retraction conclusively. However, the model seems to be the only explanation for these results. This work has been confined to Pseudomonas aeruginosa, but it seems possible that F-type pili on Escherichia coli behave in the same way since they too are RNA-phage receptors. It is hoped to apply the techniques used here to E. coli. A knowledge of the function of such pilimight be of practical importance because it might be possible to prevent drug resistance transfer via R-pili by finding an agent which prevents retraction.

I am most grateful to Professor B. W. Holloway for valuable correspondence and to Mr G. Duncan for able technical assistance. Mrs J. Riddaway kindly helped with rabbit injections.

\section{REFERENCES}

Adams, M. H. (1959). Bacteriophages. New York and London: Interscience Publishers.

Anderson, T. F., Wollman, E. L. \& JACOB, F. (1957). Sur les processus de conjugaison et de recombinaison chez Escherichia coli. III. Aspects morphologiques en microscopie électronique. Annales de l'Institut Pasteur 93, 450-455.

BRADLEY, D. E. (I962). A study of the negative staining process. Journal of General Microbiology 29, 503-516.

Bradley, D. E. (I966). The structure and infective process of a Pseudomonas aeruginosa bacteriophage containing ribonucleic acid. Journal of General Microbiology 45, 83-96.

Bradley, D. E. (1972). A study of pili on Pseudomonas aeruginosa. Genetical Research I9, 39-5I.

Brinton, C. C. (1965). The structure, function, synthesis and genetic control of the bacterial pilus and a molecular model for DNA and RNA transport in Gram-negative bacteria. Transactions of the New York Academy of Sciences 27, $1003-1054$.

Brinton, C. C., Gemski, P. \& CARnahan, J. (I964). A new type of bacterial pilus genetically controlled by the fertility factor of $E$. coli KI2, and its role in chromosome transfer. Proceedings of the National Academy of Sciences of the United States of America 52, 776-783.

CARo, L. G. \& Schnös, M. (I966). The attachment of the male-specific bacteriophage fl to sensitive strains of Escherichia coli. Proceedings of the National Academy of Sciences of the United States of America 56, $126-132$. 
CURTISs, R., III. (1969). Bacterial conjugation. Annual Review of Microbiology 23, 69-I27.

Fuerst, J. A. \& Hayward, A. C. (I969). Surface appendages similar to fimbriae (pili) on Pseudomonas species. Journal of General Microbiology 58, 227-237.

HeNRY, T. J. \& BRINTON, C. C., JUN. (197I). Removal of the coat protein of bacteriophages MI 3 or fd from the exterior of the host after infection. Virology 46, 754-763.

Holloway, B. W. (1955). Genetic recombination in Pseudomonas aeruginosa. Journal of General Microbiology I3, $572-58 \mathrm{I}$.

Holloway, B. W. (1969). Genetics of Pseudomonas. Bacteriological Reviews 33, 419-443.

LAWN, A. M. (1967). Simple immunological labelling method for electron microscopy and its application to the study of filamentous appendages of bacteria. Nature, London 214, I I 5 I-I I 52.

LAwn, A. M. \& MeYNell, E. (1972). Antibody-stimulated increase in sex pili in $\mathrm{R}^{+}$Enter obacteria. Nature London 235, 44I-442.

LOEB, T. \& ZINDER, N. D. (196I). A bacteriophage containing RNA. Proceedings of the National Academy of Sciences of the United States of America 47, 282-289.

Marvin, D. A. \& HoHn, B. (1969). Filamentous bacterial viruses. Bacteriological Reviews 33, I 72-209.

PARANCHYCH, W. (1966). Initial stages in phage RI7 infection: the role of divalent cations. Virology 28, 90-99.

Silverman, P. M. \& Valentine, R. C. (1969). The RNA injection step of bacteriophage f 2 infection. Journal of General Virology 4, I I I-I 24.

TRENKNER, E., BonHOEFFer, F. \& Gierer, A. (1967). The fate of the protein component of bacteriophage fd during infection. Biochemical and Biophysical Research Communications 28, 932-939.

VALENTINE, R. C. \& WEDEL, H. (1965). The extracellular stages of RNA bacteriophage infection. Biochemical and Biophysical Research Communications 2r, I06-1 I2.

Weppelman, R. M. \& Brinton, C. C., Jun. (197I). The infection of Pseudomonas aeruginosa by RNA pilus phage PP7: the adsorption organelle and the relationship between phage sensitivity and the division cycle. Virology 44, I-I7. 